\title{
A Bolted Moment Connection Model for Precast Column-Beam Joint
}

\author{
Selim Pul, Mehmet Şentürk \\ Engineering Faculty, Civil Engineering Department, Karadeniz Technical University \\ 61080 Trabzon, Turkey \\ spul@ktu.edu.tr; mehmetsenturk@ktu.edu.tr
}

\begin{abstract}
In this study, bolted moment connection model for precast reinforced concrete column-beam joint was developed and tested experimentally in order to obtain and compare its bearing capacity with traditional cast-in-place monolithic joint. With this purpose, a bolted moment connection behaving like a monolithic connection were designed. A full-scale T-shape beam and column were produced separately and assembled by using high strength bolts. This specimen was tested under constant axial load on column and quasi-static reverse cyclic lateral loading on beam end. Identically same monolithic specimen was also tested under the same conditions. Test results showed that bearing capacity of bolted specimen is approximately $20 \%$ higher than the capacity of monolithic one. In addition, it is observed that the shear and moment capacity of bolted joint has increased. Hence it is obtained that it is possible to build moment resisting frame structures by using the bolted moment connection suggested within this study and this system can be used for structures in seismic regions.
\end{abstract}

Keywords: Precast, bolted moment connection, quasi-static test, seismic design

\section{Introduction}

In monolithic structural systems' joint, all the internal forces are transferred between column and beam. Correspondingly, structure can have some useful abilities such as redistribution and high lateral rigidity $[1,2]$. In contrast, precast structures cannot have such kind of abilities commonly. Precast concrete structures are assembled and built by using different types of connection techniques. Therefore, it can be said that the most critical regions of precast structures are their connection zones. In case of earthquake, which enforces structures to exceed their elastic bearing capacity, in order to behave ductile and not to demolish, possible brittle damage at joints of precast concrete structures must be prevented [3]. There are two main connection types for precast concrete members called wet and dry connections (Fig 1). There are two types of dry connections. One of them is moment resisting connections that are performed by using bolts, weld and post-tensioning. Other is only shear resisting connection type which is performed by positioning the horizontal members onto vertical members without using any other connection member. By using dry connection, it is easy to assemble prefabricated members or replace the damaged members after earthquake. Despite that, moment connection is possible due to wet connection, joint regions of the members are left without concrete during prefabrication and concrete casting to joint regions are taken place at site. Because of the concrete curing duration, wet connections are slower than dry connections. Plus, disassembling and reuse of the members are not possible in wet connection.

Research carried out 1999 Kocaeli Earthquake showed that collapsed precast structures were slender and did not have enough lateral rigidity [4]. According to analytical studies after Kocaeli and Duzce Earthquakes performed by Ozden and Meydanli [5], significant amount of precast structures was not totally safe under the earthquake conditions. Large deflections of precast structures caused by earthquake can make the second order effects (P-Delta effect) more efficient. Hence, loss of stability can play a major role in collapse mechanism. It is observed that the ductility of precast structure built by using current connection technique is lower than monolithic connection. Investigation done by Belleri et al. [6] after big earthquakes in Italy showed that joints of precast industrial structures diminish the strength and ductility of the whole structures and collapses were occurred by stability lost. An examination about great number of connection types done by French et al. [7] reveal that bolted connections behave better than others. Nevertheless, at that times, bolted moment connections were not suggested due to lack of technology and production difficulties. By Ozturan et al. [8], castin-place (monolithic), composite and bolted connection for precast structures were designed and tested experimentally. Comparison of test results showed that bolted and monolithic connection behaviors are close to each other. Also, it is 
pointed out the bolted connection behave better than all other types of connections. Bolted moment connection model designed within this study provides moment resisting at joints, short construction time and replacement of members in case of damage after earthquake. Similarly, there are a great number of studies about earthquake behavior of precast columnbeam connection in technical literature [9 -15].

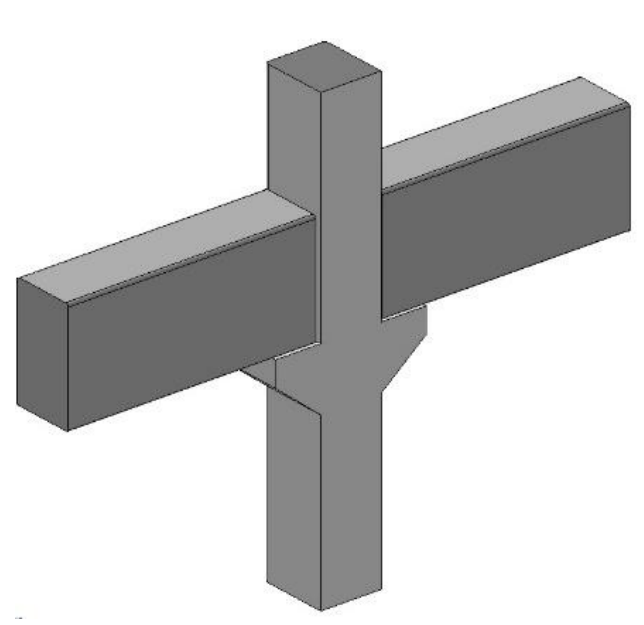

(a)

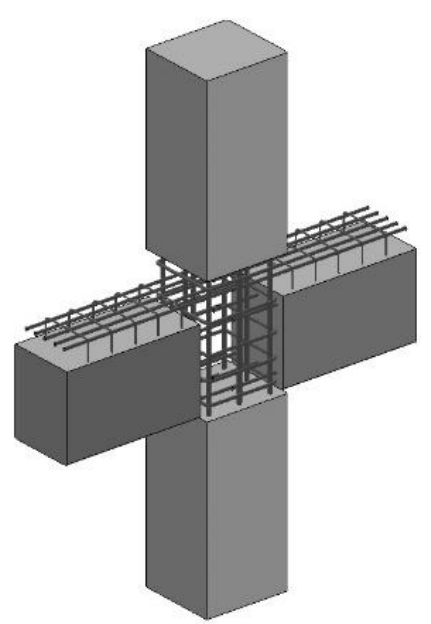

(b)

Fig. 1: Typical column - beam connection in precast members; (a) Dry connection and (b) Wet connection.

\section{Experimental Study}

\subsection{Material and Method}

This study was taken place in Structures \& Materials Lab. at KTU. A full-scale T-shape reinforced concrete columnbeam connection zone was modelled as test specimen. Precast and monolithic specimens had same dimensions and same reinforcement patterns. Beam cross-section is chosen as $250 \mathrm{x} 400 \mathrm{~mm}$ and column cross-section is chosen as $300 \mathrm{x} 300$ $\mathrm{mm}$. Longitudinal and transverse reinforcement of column member are $8 \varnothing 14$ and $\varnothing 8 / 80 \mathrm{~mm}$ respectively. Longitudinal and transverse reinforcement of beam member are $10 \varnothing 14$ and $\varnothing 8 / 100 \mathrm{~mm}$ respectively. At the tip of beam, where lateral load applies, was strengthened with extra transverse reinforcement by $50 \mathrm{~mm}$ spaced transverse ties. Dimensions and reinforcement details of the specimens are shown in Fig 2.

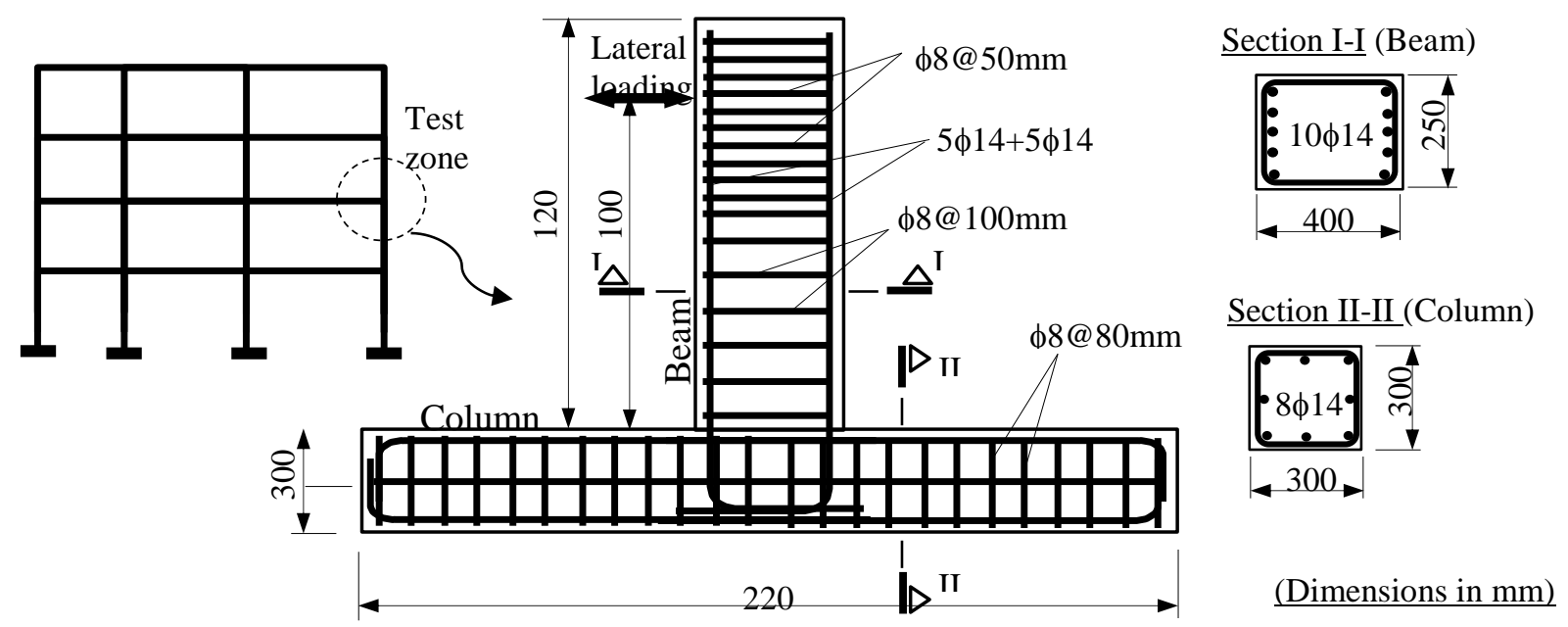

Fig. 2: Dimensions and reinforcement details of test specimens. 
Conventional concrete mixture ratios for specimens are given in Table 1. Two castings were performed at different times for monolithic and precast specimen. CEM II B-M (P-LL) $32.5 \mathrm{R}$ type cement was used. $150 \mathrm{~mm}$ cubic concrete specimens were taken from the mixtures. For the monolithic specimen, compressive strength of the concretes in 28 days and test day are $30 \mathrm{MPa}$ and $43.2 \mathrm{MPa}$ respectively. For the precast specimen, compressive strength of the concretes in 28 days and test day are $31 \mathrm{MPa}$ and $42.9 \mathrm{MPa}$ respectively. Mechanical properties of deformed bars used for production of specimens are given in Table 2.

Table 1: Concrete Mix Proportions.

\begin{tabular}{|c|c|c|c|c|c|c|}
\hline \multicolumn{3}{|c|}{ Aggregate $\left(\mathrm{kg} / \mathrm{m}^{3}\right)$} & \multirow{2}{*}{$\begin{array}{l}\text { W/C } \\
\text { Ratio }\end{array}$} & \multirow{2}{*}{$\begin{array}{l}\text { Water } \\
\left(\mathrm{kg} / \mathrm{m}^{3}\right)\end{array}$} & \multirow{2}{*}{$\begin{array}{l}\text { Cement } \\
\left(\mathrm{kg} / \mathrm{m}^{3}\right) \\
\end{array}$} & \multirow{2}{*}{$\begin{array}{c}\text { Super- Plasticize } \\
\left(\mathrm{kg} / \mathrm{m}^{3}\right)\end{array}$} \\
\hline Fine $(\leq 4.0 \mathrm{~mm})$ & Coarse $(>4.0 \mathrm{~mm})$ & Total & & & & \\
\hline 694 & 1041 & 1735 & 0.50 & 200 & 400 & 4.0 \\
\hline
\end{tabular}

Table 2: Mechanical Properties of Deformed Bars.

\begin{tabular}{|c|c|c|c|}
\hline Diameter $(\mathrm{mm})$ & Yield Strength (MPa) & Ultimate Strength (MPa) & Strain at Rupture (\%) \\
\hline 8 & 455 & 608 & 25.7 \\
\hline 14 & 490 & 598 & 20.6 \\
\hline
\end{tabular}

For the proper concrete placement, rodding and vibration were applied carefully. After casting, specimens were kept wet at least 1 week. Strain gauges were installed to both side's longitudinal bars at the potential plastic hinge zone of beam in order to measure axial strain of longitudinal reinforcements. Load cells were used in order to measure applied load. Plus, linear potentiometric displacement transducers (LPDT) were used for measuring displacements. Axial loaded column ends were pin supported. Experimental setup is shown in Fig 3.

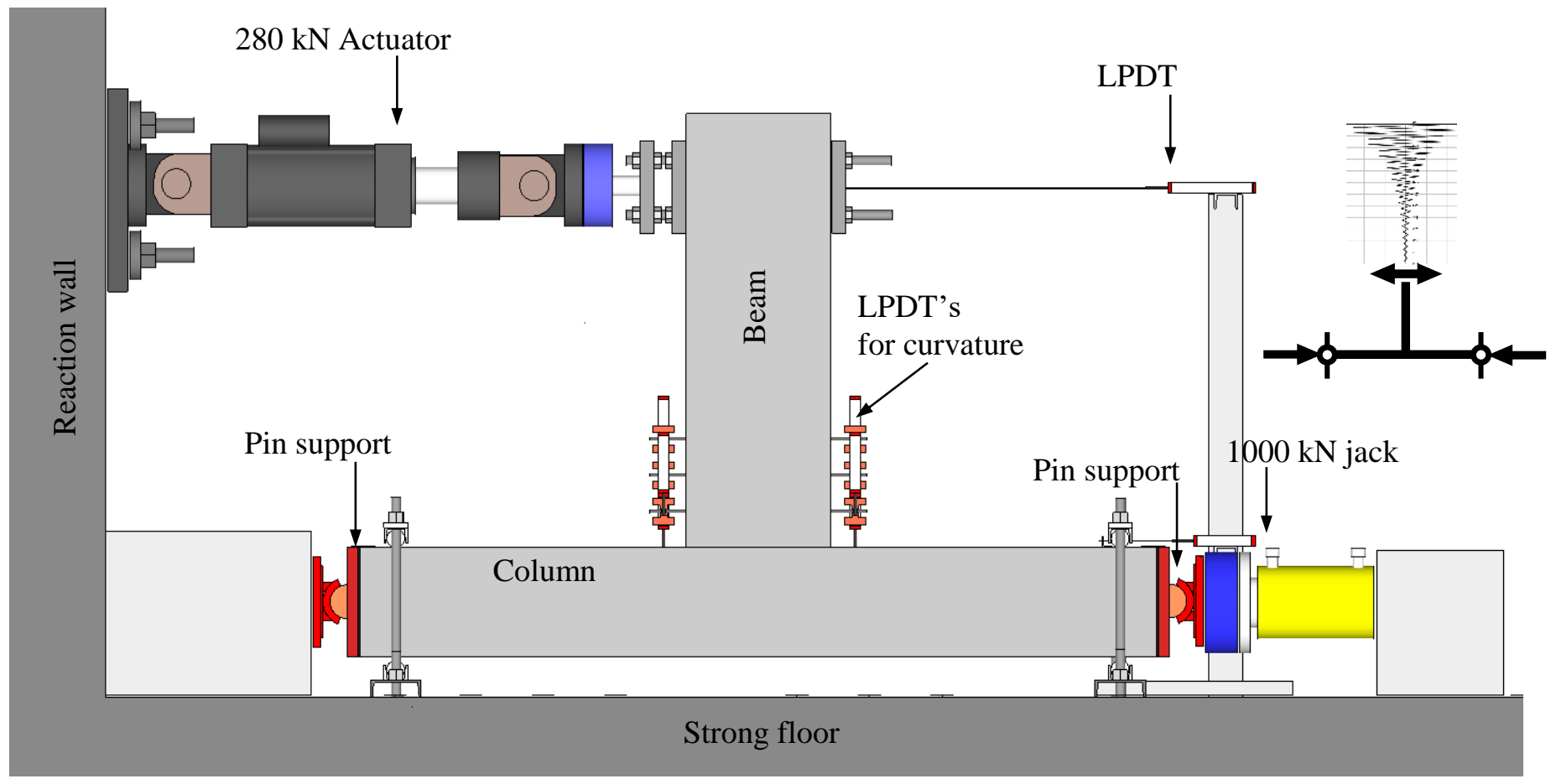

Fig. 3: Experimental Setup. 
For the purpose of transferring moment between column and beam, bolted moment connection system was designed. In this system, connection is performed with steel plates, which are located at beam end and column face.

By using finite element analysis, preliminary sizing was done. Column and beam plate thicknesses are obtained from this pre-analyses as $10 \mathrm{~mm}$ and $20 \mathrm{~mm}$ respectively and steel grade were St-37 (proof strength of $240 \mathrm{MPa}$ ). In addition, beam plate was stiffened by using two plates sized $10 \times 50 \mathrm{~mm}$ all along (Fig. 4 a). For moment connection, three M27 high strength hex bolts ( 8.8 grade) were used at both side of the beam. In total, six bolts were used symmetrically. Views from the beam end plate and column ride plate are shown in Fig. 4. For fastening the column rider plate to concrete, anchorage rods made from reinforcing bars were welded to plate (see Fig. $4 \mathrm{~b}$ ). Plus, in order to increase the number of threads, high nuts were welded to each hole. Assembled and disassembled form of entire connection system is shown in Fig. $5 \mathrm{~b}$ and Fig. 5 a respectively.

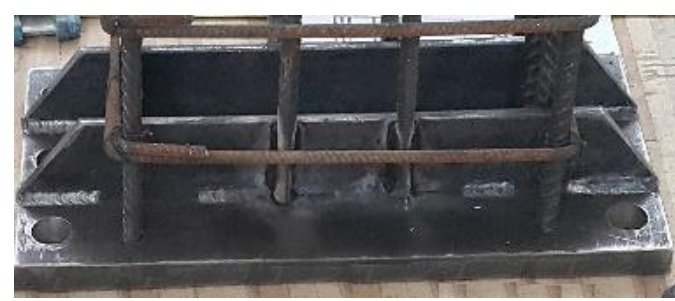

(a)

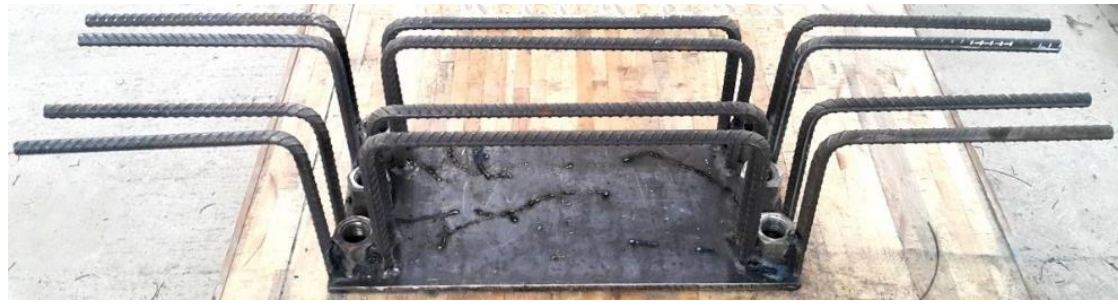

(b)

Fig. 4: Connection plates; (a) Beam end plate, (b) Column rider plate.

For the lateral loading, quasi-static reversal cyclic loading protocol given in FEMA 461 [16] was used (Fig. 6). A computer controlled servo-hydraulic linear actuator with $280 \mathrm{kN}$ push and $170 \mathrm{kN}$ pull capacity was used for the loading.

An Enerpac brand hydraulic jack with $1000 \mathrm{kN}$ capacity and a hand pump were used to apply constant axial load onto the column during test. Constant axial load level was chosen as $10 \%$ of axial load bearing capacity of column $\left(0.1 A_{g} f_{c o}\right)$. Where, $A_{g}$ is gross area of column cross-section, $f_{c o}$ is unconfined concrete compressive strength. Axial load level continuously observed during the test to keep it constant.

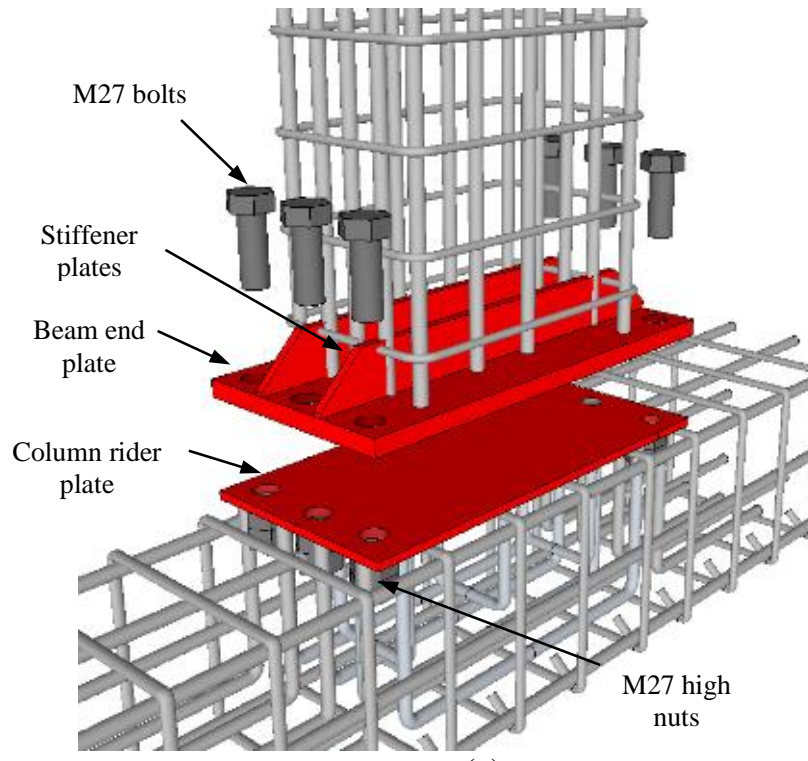

(a)

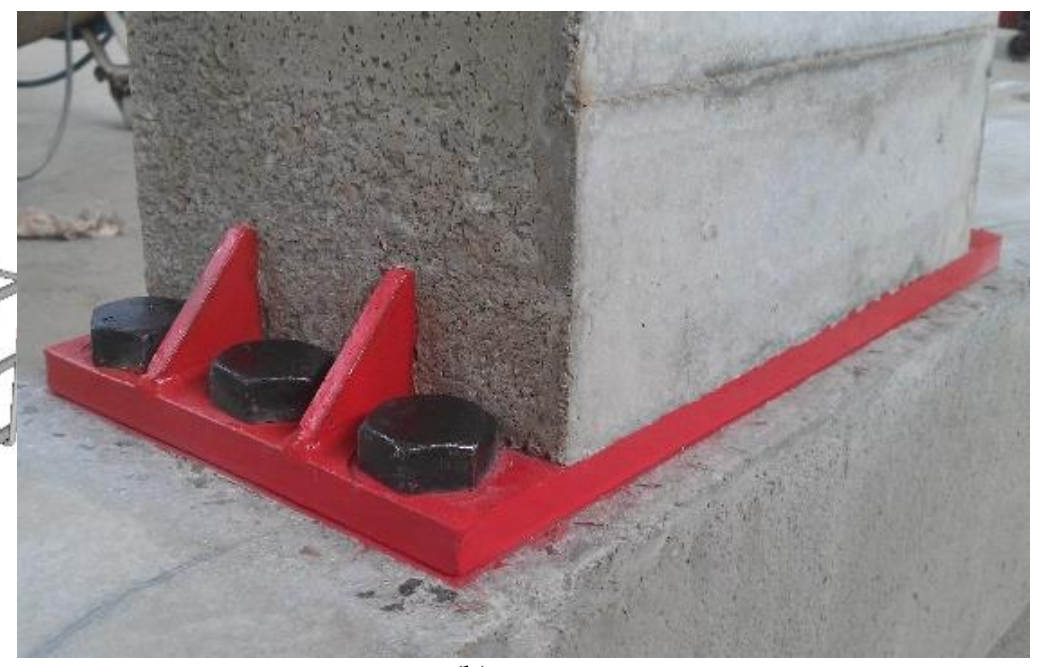

(b)

Fig. 5: (a) Reinforcements of bolted connection zone with disassembled view and (b) view of assembled form. 


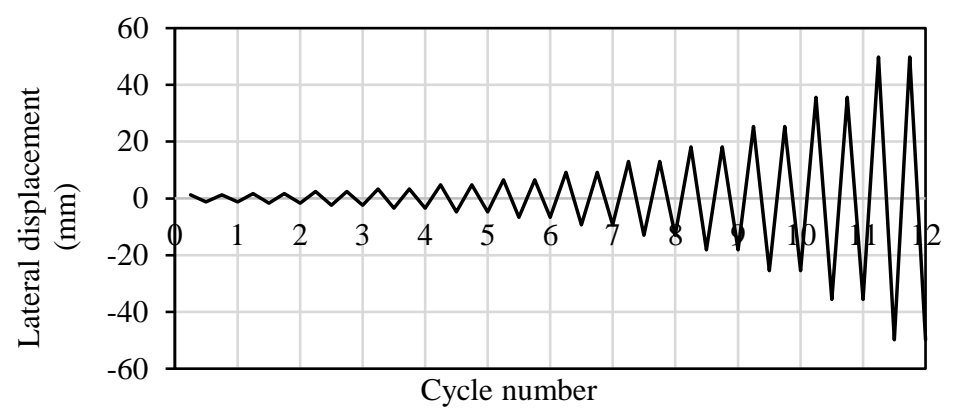

Fig. 6: Applied lateral load protocol.

\subsection{Test Results}

Test results of both specimens are given in Fig. 7. After-test views of the specimens are given in Fig. 8.

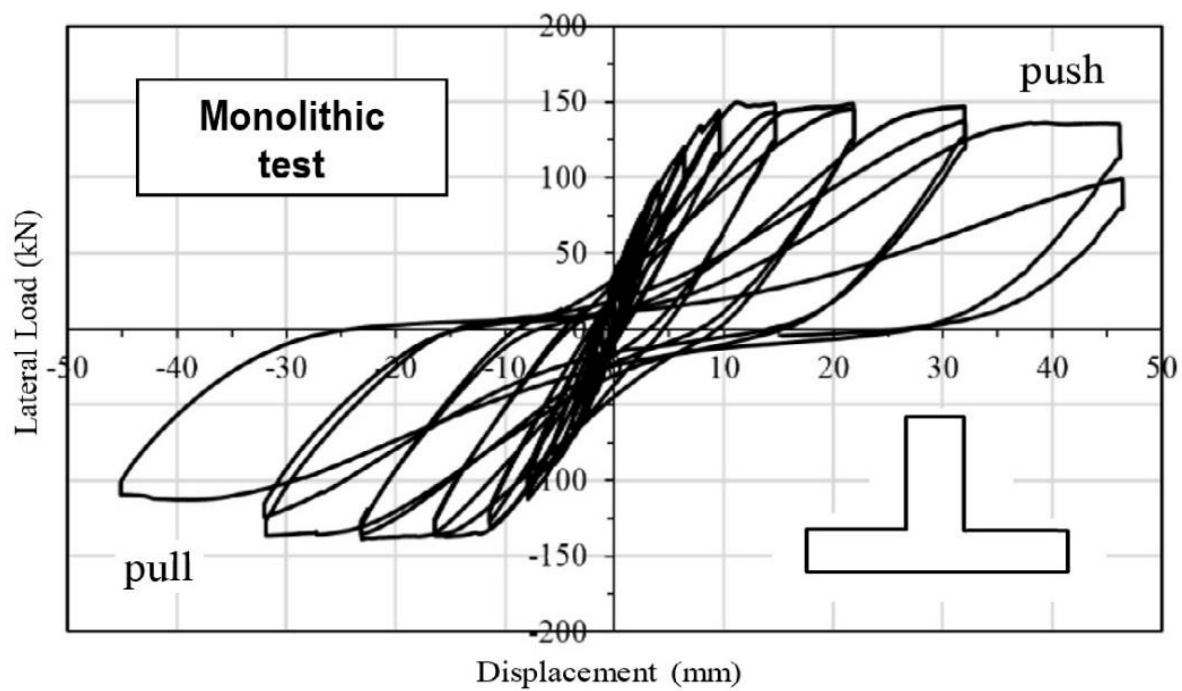

(a)

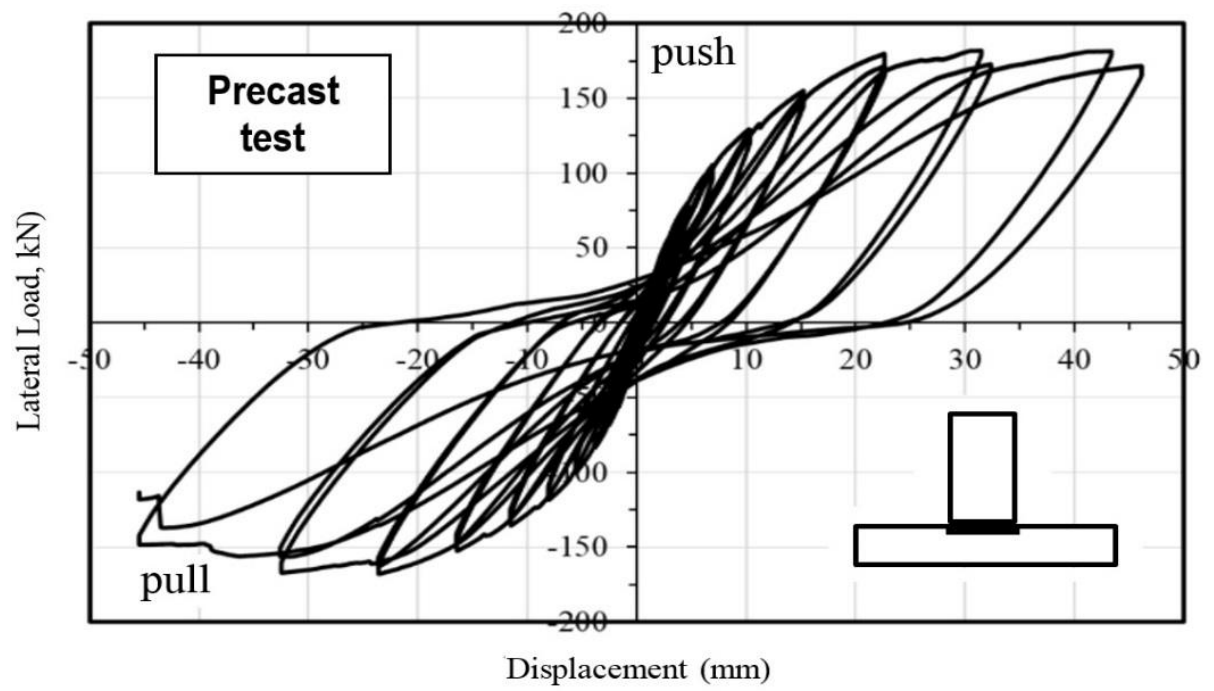

(b)

Fig. 7: Cyclic behaviour of test specimens; (a) Monolithic specimen and (b) Precast specimen. 


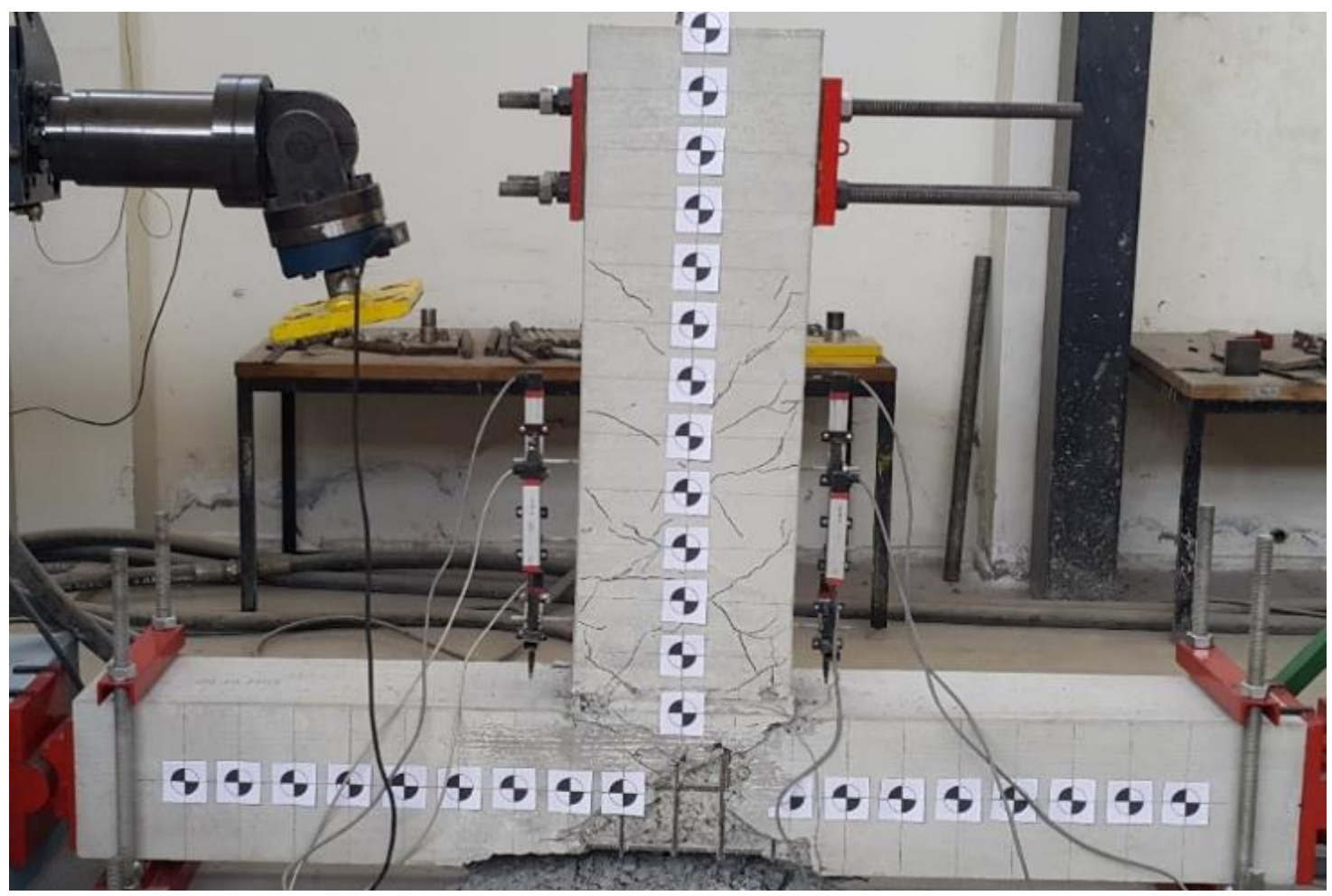

(a)

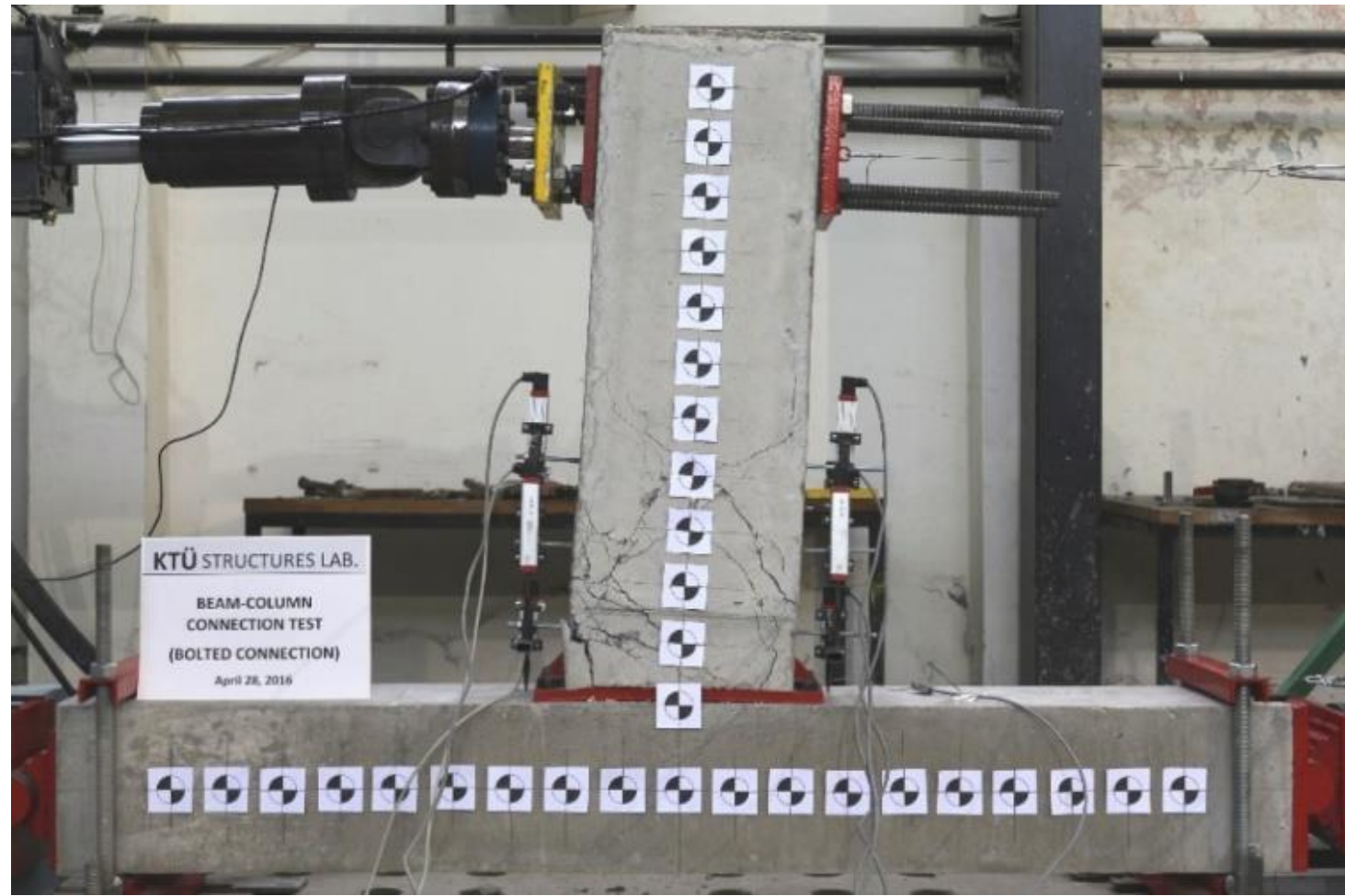

(b)

Fig. 8: After-test views of (a) monolithic and (b) precast specimens. 


\subsection{Discussion}

Although identically same specimens were cast at different times, the compressive strength of cubic concrete specimens taken from each casting were approximately equal. Therefore, results of each experiment can be compared directly.

According to observations, monolithic specimen was reached its bearing capacity due to shear failure at column-beam connection region. In contrast, precast specimen was reached its bearing capacity with ductile behavior where concrete at compression zone was crushed and rebar at tension zone was ruptured at high drift ratio. Experimental curves from test results of monolithic and precast members are given in Fig. 9 at the same chart with their envelopes. According to this curves, bearing capacity of bolted precast specimen is $20 \%$ higher than capacity of monolithic specimen. This rehabilitation may have been caused by anchorage rods placed in connection zone and rider plate places on the column's face.

In monolithic specimen, after the curve is reached horizontal, slope of the envelope tends to decrease at both pushing and pulling. In precast specimen, slope of envelope become horizontal at higher lateral displacement ratios. Consequently, by comparing the test results, it can be said that bolted precast column-beam connection can behave at least like monolithic connection.

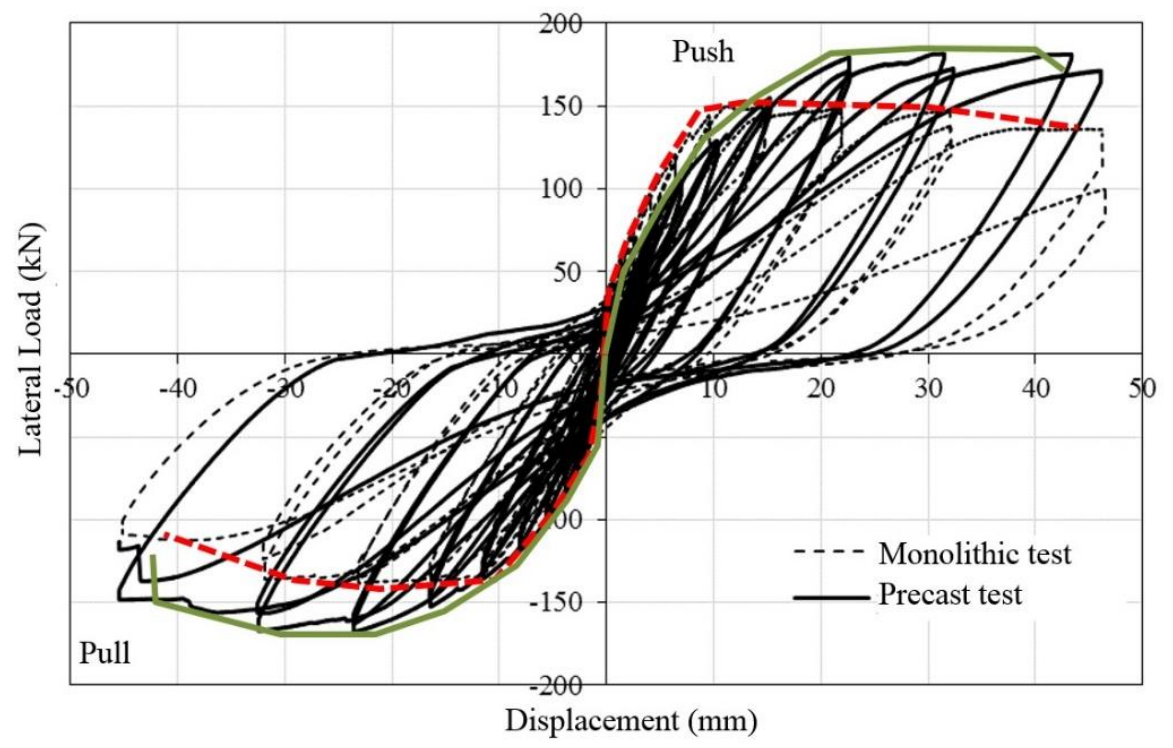

Fig. 9: Comparison of the test results and envelopes.

\section{Conclusion}

In this study, a bolted moment connection system was designed and tested. With the suggested moment connection, the aim of this study is providing precast structures that behave like monolithic cast-in-place structures. Thus, structures built by using this technique can be built as fast as precast structures and as high performance as monolithic structures. Preliminary results obtained from this ongoing study are summarized below.

- It is possible to build moment resisting frame structures by using the bolted moment connection suggested in this study.

- Because of the fact that the bolted connection system recommended in this study can transfer moment between column and beam, this system can be used for structures in seismic regions.

- By using bolted moment connection, it is possible to replace damaged members.

For the purpose of developing high performance connection system for precast structures, obtaining the design rules and using this type of connection safely, there has to be performed more experimental study with reinforced concrete specimens with different types and sizes. Hereby, disadvantages of connection systems can be obtained and safety of moment connections can be proved. 


\section{References}

[1] Requirements for design and construction of reinforced concrete structures, Turkish Standards Institution, TR, 2000.

[2] U. Ersoy and G. Ozcebe, "Betonarme: Temel Illkeler TS-500-2000 ve Türk Deprem Yönetmeliğine (1998) Göre Hesap," Evrim Yayınevi, 2001 (in Turkish).

[3] Specification for Buildings to be Built in Seismic Zones, General Directorate of Natural Disasters, TR, 2007.

[4] M. Posada and S. Wood, "Seismic performance of precast industrial buildings in Turkey," in 7th US National Conference on Earthquake Engineering (7NCEE), 2002.

[5] S. Ozden and H. Meydanl1, "1999 Marmara Depremlerinde Prekast Endüstri Yapılarında Gözlenen Deprem Hasarları ve Sebepleri,” Kocaeli Bülten, TMMOB İnşaat Mühendisleri Odası, 2003 (in Turkish).

[6] A. Belleri, E. Brunesi, R. Nascimbene, M. Pagani and O. Riva, "Seismic performance of precast industrial facilities following major earthquakes in the Italian territory," Journal of Performance of Constructed Facilities, vol. 29, no. 5, 04014135, 2014.

[7] C. W. French, M. Hafner, V. Jayashankar, "Connections between precast elements-failure within connection region," Journal of Structural Engineering, vol. 115, no. 12, pp. 3171-3192, 1989.

[8] T. Ozturan, S. Ozden, O. Ertas, "Ductile connections in precast concrete moment resisting frames," Concrete Construction, vol. 9, no. 11, 2006.

[9] J. E. Ochs, M. R. Ehsani, "Moment resistant connections in precast concrete frames for seismic regions," PCI Journal, vol. 38, no. 5, pp. 64-75, 1993.

[10] S. Alcocer, R. Carranza, D. Perez, "Behaviour of a precast concrete beam-column connection," In Memorias, 12th World Conference of Earthquake Engineering, Auckland, New Zealand, 2000.

[11] T. Tankut, H. H. Korkmaz, "Performance of a precast concrete beam-to-beam connection subject to reversed cyclic loading," Engineering Structures, vol. 27, pp. 1392-1407, 2005.

[12] H. K. Choi, Y. C. Choi, C. S. Cho, "Development and testing of precast concrete beam-to-column connections," Engineering Structures, vol. 56, pp. 1820-1835, 2013.

[13] H. Parastesh, I. Hajirasouliha, R. Ramezani, "A new ductile moment-resisting connection for precast concrete frames in seismic regions: An experimental investigation," Engineering Structures, vol. 70, pp.144157.

[14] E. Yuksel E, H. F. Karadogan, I. E. Bal, A. Ilki, A. Bal, P. Inci, "Seismic behavior of two exterior beam-column connections made of normal-strength concrete developed for precast construction," Engineering Structures, vol. 99, pp. 157-172, 2015.

[15] H. Zibasokhan, F. Behnamfar, K. Behfarnia, "The new proposed details for moment resisting connections of steel beam tocontinuous concrete column," Advances in Structural Engineering, vol. 19, no. 1, pp.156-169, 2016.

[16] FEMA-461: Interim Testing Protocols for Determining the Seismic Performance Characteristics of Structural and Nonstructural Components, Federal Emergency Management Agency, Washington/USA, 2007. 